\title{
Initial studies into the characterisation of ripening stages of Emmental cheeses by mid-infrared spectroscopy
}

\author{
Sandra Teresita Martín Del CAmpo ${ }^{1,2 * *}$, Nicolas BonnaIre ${ }^{1,2}$, \\ Daniel PiCQue ${ }^{1,2 *}$, Georges Corrieu ${ }^{1,2}$ \\ ${ }^{1}$ AgroParisTech, UMR 782, Génie et microbiologie des procédés alimentaires, \\ BP 1, 78850 Thiverval-Grignon, France \\ ${ }^{2}$ INRA, UMR 782, Génie et microbiologie des procédés alimentaires, \\ BP 1, 78850 Thiverval-Grignon, France
}

Received 22 April 2008 - Accepted 18 December 2008

\begin{abstract}
Experimental Emmental cheeses were analysed to evaluate the potential of mid-infrared spectroscopy to follow the ripening process. Cheeses were sampled at seven different ripening stages and were analysed. The infrared spectra were obtained by placing the cheese slices directly over the attenuated total reflectance crystal. Analysis of variance showed significant $(P \leq 0.05)$ absorbance changes between spectral sets in the regions assigned to vibrations of alcohol, amide and hydrocarbon chains. Principal component analysis (PCA) made it possible to describe four groups including samples ripened during 21, 27 and 34 days (G1), 51 and 58 days (G2), 65 days (G3) and the samples at the end of the ripening (mould opening, about 85 days) (G4). Using general discriminant analysis of spectral data, it is not possible to correctly distinguish samples according to seven dates of sampling, but samples belonging to the four groups identified by PCA are predicted well by the regression model.
\end{abstract}

mid-infrared spectroscopy / cheese ripening / Emmental / spectral evolution / PCA / discriminant analysis

\begin{abstract}
摘要 - 中红外光谱法研究埃门塔尔干酪成熟期间的特性。利用中红外光谱法对埃门塔尔干 酪整个成熟工艺过程进行了分析，从而评价中红外光谱法在这方面分析的优势。共分析了 7 个不同成熟阶段的埃门塔尔干酪样品。样品的红外光谱图是通过将干酪压片直接放置在 红外光谱仪的衰减全反射晶片上测定而得到。方差分析 (ANOVA) 结果显示在谱图中的 醇、酰胺及烃链等官能团的振动区域内具有显著的吸光度差异。通过主成份分析 (PCA) 可以 根据埃门塔尔干酪不同成熟度而划分为四类干酪样品, 这四类样品包括 G1 组（成熟时间分 别为 $21 、 27$ 和 34 天的干酪样品设为第一组), G2 组 (成熟时间分别为 51 和 58 天的干酪样品设 为第二组), G3 (成熟时间为 65 天的干酪样品设为第三组), G4 (成熟末期, 约为 85 天的干酪 样品设为第四组)。通过对光谱数据进行判別函数分析 (GDA) 并不能正确区分上述 7 个 不同成熟阶段的干酪样品, 但是根据主成份分析结果显示, 所建立的回归模型可以很好地 预测这些样品属于上述的四类样品组。
\end{abstract}

\section{中红外光谱 / 干酪成熟 / 埃门塔尔干酪 / 光谱评定 / 主成分分析 / 识别分析}

* Corresponding author (通讯作者): picque@grignon.inra.fr

** Current address: Instituto Tecnológico y de Estudios Superiores de Monterrey, Campus Querétaro, Departamento de Industrias Alimentarias, México. 
Résumé - Caractérisation des stades d'affinage de fromages de type Emmental par spectroscopie moyen infrarouge - Étude préliminaire. Des fromages expérimentaux de type Emmental ont été analysés pour évaluer le potentiel de la spectroscopie moyen infrarouge pour caractériser l'affinage. Des échantillons de fromage ont été prélevés à sept stades différents d'affinage et analysés directement. Les spectres infrarouges ont été obtenus en plaçant les tranches de fromage sur un cristal de réflexion totale atténuée (ATR). L'analyse de variance a montré des changements d'absorbance significatifs $(P \leq 0.05)$ dans les régions spectrales assignées aux vibrations des fonctions alcools, amides et des chaînes carbonées. L'analyse en composantes principales permettait de décrire quatre groupes incluant les échantillons affinés pendant 21, 27 et 34 jours (G1), 51 et 58 jours (G2), 65 jours (G3) et en fin d'affinage (MO, ouverture des meules, environ 85 jours). Par analyse discriminante des données spectrales, il n'était pas possible de classer correctement les échantillons selon les sept dates de prélèvements. Cependant, les échantillons appartenant aux quatre groupes identifiés par ACP ont bien été prédits par le modèle de régression.

spectroscopie moyen infrarouge / affinage / Emmental / évolution spectrale / ACP / analyse discriminante

\section{INTRODUCTION}

During the ripening of semi-hard cheeses, important biochemical changes due to proteolysis, glycolysis and lipolysis occur. These catalytic reactions lead to significant changes in composition and sensory properties. Proteolysis [7, 27, 30] in Emmental and other related Swiss-type cheeses, as well as lipolysis [2, 8, 18] and glycolysis [30], has been described in different publications.

The evaluation of these phenomena has traditionally been performed using physico-chemical methods such as the analysis of $\mathrm{pH}$ [27], dry matter [30], fat, protein and protein fractions $[27,30]$ and the amount of free amino acids [8]. More sophisticated and specific instrumental analytical methods such as liquid [7, 27, 30] and gas $[2,8,18]$ chromatography have also been used to determine proteins, peptides, amino acids, free fatty acids and triglycerides of cheese. Differential scanning calorimetry and confocal laser scanning microscopy permitted the determination of thermal properties and characterisation of changes in the organisation of fat during the manufacture of Emmental cheese in relation to its quality [18]. However, these analytical tools are expensive and timeconsuming, and these cannot be used for simple estimation of cheese ripening time.

In cheese factories, evaluation of ripening stage is made by the cheese maker on the basis of a limited number of measurements ( $\mathrm{pH}$ and weight) as well as on the basis of visual and tactile examination. This kind of evaluation provides limited information about the evolution of proteolysis, glycolysis and lipolysis. Due to the known effects of these enzymatic reactions on the end quality of cheese, it is necessary to develop new, rapid and simple methodologies to help the cheese maker to improvise the ripening process.

Fourier transform infrared spectroscopy (FTIR) is a fast, direct and reliable method that makes possible the acquisition of specific information about different analytical parameters simultaneously, principally in the $3000-400 \mathrm{~cm}^{-1}$ region. The bands of this specific region are associated with the vibrations of molecular functional groups $[10,11]$. In addition, this methodology is ideally suitable to follow compositional and molecular changes in dairy products. In cheeses, the bands associated with 
proteins, fats, lactose and lactic acid are well known.

Different chemometric tools are required first to analyse the spectroscopic data to subsequently correlate the excitation of different bands with chemical and physical information or to extract the important information about the molecular structure of cheese [9].

FTIR has been successfully used to determine the variety of Emmental cheeses [24] and the region of origin of cheeses coming from five European countries [10]. Cheese composition has also been predicted by FTIR. Non-protein nitrogen, watersoluble nitrogen contents and $\mathrm{pH}$ were predicted with good accuracy from midinfrared spectra of European Emmental cheeses (coefficient of determination $R^{2} \geq 0.80$ and the ratio of standard deviation to root mean square error prediction RPD $\geq 2$ ).

Fat and total nitrogen contents were estimated with a lower accuracy but the results can be improved by using of near infrared (NIR) spectra [12]. The same authors demonstrated the use of NIR spectroscopy to predict few sensory attributes of the same cheeses [13]. Recently, Koca et al. [14] predicted the content of free fatty acids in Swiss cheeses using FTIR associated with partial least square regression. The authors correlated the integrated areas of the $3000-2800$ and $1775-1680 \mathrm{~cm}^{-1}$ regions with concentration of propionic, acetic and butyric acids.

The objective of this research was to evaluate the potential of FTIR to follow the ripening of Emmental cheeses. Nine different cheeses were sampled at seven different ages and were analysed using an attenuated total reflectance (ATR) sample presentation. The spectral evolutions were analysed using analysis of variance (ANOVA) and principal component analysis (PCA) procedures. Discrimination of different aged cheeses was performed by general discriminant analysis (GDA).

\section{MATERIALS AND METHODS}

\subsection{Cheese preparation and ripening}

For this study, experimental Emmental cheeses were manufactured in the French Technical Institute of Cheese (ITFF, La Roche sur Foron, France) according to the usual process. They were manufactured in the same week by the same cheese maker and from the same standardised milk (fat: $30-31 \mathrm{~g} \cdot \mathrm{L}^{-1}$ ) heated at $63{ }^{\circ} \mathrm{C}$ for $30 \mathrm{~s}$. The milk was supplemented with $0.05 \mathrm{~mL} \cdot \mathrm{L}^{-1}$ of a $\mathrm{CaCl}_{2}$ solution $\left(510 \mathrm{~g} \cdot \mathrm{L}^{-1}\right)$. Before renneting $\left(0.25 \mathrm{~mL} \cdot \mathrm{L}^{-1}\right.$, Berthelot, ABIA S.A., Meursault, France), the milk was ripened in the vat for $1 \mathrm{~h}$ at $32{ }^{\circ} \mathrm{C}$ with thermophilic lactic acid bacteria as starters; $0.14 \%$ of Streptococcus thermophilus (PAL ITG ST 82-87, Standa, Caen, France) first grown at $42{ }^{\circ} \mathrm{C}$ for $4 \mathrm{~h}$ on Mastar 412A medium (Rhodia, DangéSaint-Romain, France), $0.015 \%$ of Lactobacillus delbrueckii subsp. lactis first grown at $42{ }^{\circ} \mathrm{C}$ for $6 \mathrm{~h}$ on Phagex medium (Standa, Caen, France) and propionic acid bacteria (PAL ITG P9, Standa, $0.4 \%$ of Propionobacterium freudenreichii subsp. shermanii) as a secondary starter. The coagulation time was about $25 \mathrm{~min}$. After another $7 \mathrm{~min}$, the curd was cut into grains (diameter: $3 \mathrm{~mm}$ ) and stirred for $5 \mathrm{~min}$ before cooking to $53{ }^{\circ} \mathrm{C}$ in $30 \mathrm{~min}$. After cooking, the stirring continued for $30 \mathrm{~min}$ followed by cooling to $51{ }^{\circ} \mathrm{C}$ for moulding. After $6 \mathrm{~h}$ under pressure (2 bar), the cheese was stored for $15 \mathrm{~h}$ at $20^{\circ} \mathrm{C}$ then for $5 \mathrm{~h}$ at $12{ }^{\circ} \mathrm{C}$. After salting (day (d) 1) during $48 \mathrm{~h}$ storage at $12{ }^{\circ} \mathrm{C}$, the cheeses were preripened for 20 days in a cellar with an internal temperature ranging from 8 to $10{ }^{\circ} \mathrm{C}$. From d20 until $\mathrm{d} 34$, the cheeses were moved to a temperate ripening chamber at $15-16{ }^{\circ} \mathrm{C}$. On d34, they were transferred into a hot ripening chamber and kept at $22-23{ }^{\circ} \mathrm{C}$ and $84-86 \%$ relative humidity for $\sim 40$ days until mould opening (MO, d85). After MO, 
the cheeses were placed in a cold ripening chamber at $6{ }^{\circ} \mathrm{C}$ for $\sim 15$ days. The global composition target for these cheeses was $62 \%$ of dry extract, a fat/dry matter ratio of $47 \%$ and $\mathrm{a} \mathrm{pH}$ of 5.30 at the beginning of ripening.

\subsection{Sampling}

About five to nine cheeses were sampled at different ripening times. For each sample, a cylinder of 15-20 g was used. In the temperate cellar, samplings were made at the cellar entrance (d20) and after 7 days inside the cellar (d27). In the hot cellar, samplings were performed at the entrance $(\mathrm{d} 34)$ and 17 days (d51), 24 days (d58) and 30 days (d64) later inside the cellar. The last sampling was made at the end of ripening when moulds were opened (MO).

\subsection{Infrared spectroscopy}

The cylinders were cut longitudinally to obtain cheese slices of $7 \mathrm{~cm} \times 1 \mathrm{~cm} \times$ $0.5 \mathrm{~cm}$ that were analysed directly by infrared spectroscopy. Sample spectra were recorded in the $4000-650 \mathrm{~cm}^{-1}$ region with a Magna IR-750 spectrometer (Thermo Electron, Madison, WI, USA) equipped with a deuterated triglycine sulfate detector and a horizontal $\mathrm{ZnSe}\left(45^{\circ}\right.$ and 12 reflections) ATR accessory. The cheese slices were placed in the ATR trough plate (same dimensions of the cheese slices) and covered with the ATR cover without any supplementary pressure. Each spectrum was the mean of 32 scans taken at $4 \mathrm{~cm}^{-1}$ resolution (data spacing $1.928 \mathrm{~cm}^{-1}$ ) and the ATR crystal spectrum was subtracted from them. The Happ-Gentzel apodisation was used. Val Q Software (Thermo Electron) was used to check the performance of the spectrometer and to perform the validation of spectral measurements over time.

The water spectra were subtracted and the baseline was corrected using OMNIC 4.1a Software (Thermo Electron, Les Ulis,
France). The water subtraction was carried out according to the methodology reported by Martín del Campo et al. [19]. As in cheese spectra, there is a peak at 1800 $1700 \mathrm{~cm}^{-1}$, but only the area between 2300 and $1900 \mathrm{~cm}^{-1}$ was used to calculate the subtraction factor. The baseline correction was done manually in six points $(3000,2850,1800,1700,1490$ and $\left.950 \mathrm{~cm}^{-1}\right)$.

\subsection{Statistical analysis}

To standardise spectral the responses of the different cheese groups, the whole spectra were normalised considering four regions: $3030-2750, \quad 1800-1700,1700-$ 1490 and $1490-950 \mathrm{~cm}^{-1}$. For each region, every absorbance value was divided by the sum of the spectrum values [19]. Once each region was normalised, each spectrum was reconstructed. The statistical analyses were carried out using the STATISTICA Software (StatSoft, Paris, France).

ANOVA was carried out to identify individual bands showing significant absorbance changes throughout ripening $(P \leq 0.05)$. Since the samples were taken from different cheeses, every observation was taken as an independent block and was analysed with the model:

$$
y_{i j}=\mu+\tau_{i}+\beta_{j}+\varepsilon_{i j},
$$

where $y_{i j}$ is the $j^{\text {th }}$ observation on the $i^{\text {th }}$ treatment, $\mu$ the common effect for the whole experiment, $\tau_{i}$ the $i^{\text {th }}$ treatment effect, $\beta_{j}$ the effect of the $i^{\text {th }}$ block and $\varepsilon_{i j}$ represents the usual term NID $\left(0, \sigma^{2}\right)$ of the random error.

The Fisher least square difference (LSD) test was performed for each significant factor, and the confidence intervals were calculated using the mean square error of each ANOVA. The LSD is a pairwise test that compares the difference between each pair of mean values and therefore makes it possible to group them. The mean values 
without a common letter were significantly different at a level of significance of $5 \%$ $(P \leq 0.05)$.

Later, PCA was done in the same spectral set as that analysed using ANOVA to evaluate the evolution throughout ripening rather than that of the selected bands.

Finally, GDA was applied to the infrared spectra $\left(3030-2750\right.$ and $\left.1800-950 \mathrm{~cm}^{-1}\right)$ to evaluate the potential of infrared spectroscopy to discriminate the Emmental cheeses according to their ripening stage. GDA is a statistical tool that generates discriminant rules or functions to classify the experimental units in two or more populations defined in a unique way. Those functions could be interpreted as multiple regression equations since they try to predict a score from an adjusted sum of predictors. However, since in GDA the dependent variables are not parametric, a logistic regression is used.

Additionally, it allowed the reduction in the number of initial variables by selecting a subset of measured, uncorrelated variables. The aim was to predict the membership of one individual to a particular class based on predictor variables.

The discrimination was performed by taking the cheese age as a classification criterion according to the seven samplings (noted 1-7) or the four groups and the corresponding infrared spectrum. The whole spectral collection was divided into three sets: one calibration set (30 samples), one cross-validation set (14 samples) and one prediction set (14 samples).

To avoid an overfitting problem and to minimise the model size, a selection of the discriminant bands was performed using the forward stepwise method ( $P$ inclusion 0.05 and $P$ exclusion 0.05 ). This selection procedure is based on the evaluation of equal mean values between the sets hypothesis for each variable candidate to be discriminatory. The selected variables were those with a significant $(P<0.05)$ $F$ value.

\section{RESULTS AND DISCUSSION}

\subsection{Spectral evolution}

The evolution throughout ripening of normalised infrared spectra (3050-2800 and $1800-1000 \mathrm{~cm}^{-1}$ ) of Emmental cheeses showed slight differences (Fig. 1). The ANOVA and Fisher LSD analysis (Tab. I) of the spectra made it possible to identify the significant absorbance $(A)(P \leq 0.05)$ changes related to the degree of ripening.

The changes associated with carbohydrates and organic acids were observed in the $1490-1000 \mathrm{~cm}^{-1}$ region (Fig. 1A). The $\sim 1161 \mathrm{~cm}^{-1}$ peak, which was related to the sum of lactose (tertiary alcohol $v$ $\mathrm{C}-\mathrm{OH}$ ), monosaccharides (endocyclic oxygen $v \mathrm{C}-\mathrm{O})[1,17]$ and the ester link of fats ( $v$ C-O) [19] remained steady until the introduction of cheeses into the hot cellar (d34) $\left(A_{34}=0.0102\right)$, then decreased until d65 $\left(A_{65}=0.0089\right)$ and increased up to the end of ripening $\left(A_{85}=0.0129\right)$. The evolution of this band cannot be attributed to carbohydrate concentration changes because during Emmental elaboration, the hydrolysis of residual lactose and the resulting monosaccharides is done in the first $24 \mathrm{~h}$ of fabrication and before salting. Therefore, its concentration was virtually nil at the beginning of ripening [4]. Nevertheless, the observed evolutions were congruent with changes due to lipolysis and with the generation of organic acids, as it was previously reported in Emmental cheeses [21, 22]. During ripening in the hot cellar, the propionic bacteria metabolised L-lactate forming propionate, acetate and $\mathrm{CO}_{2}$ [21].

The change of the band at $\sim 1115 \mathrm{~cm}^{-1}$ associated with the sum of lactate and monosaccharides $(v \mathrm{C}-\mathrm{OH})[23]$ was significant (Tab. I). The signal showed an evolution in two steps; initially the signal increased significantly during the ripening in the temperate cellar showing a maximum at $\mathrm{d} 27\left(A_{27}=0.0065\right)$ while, subsequently, 

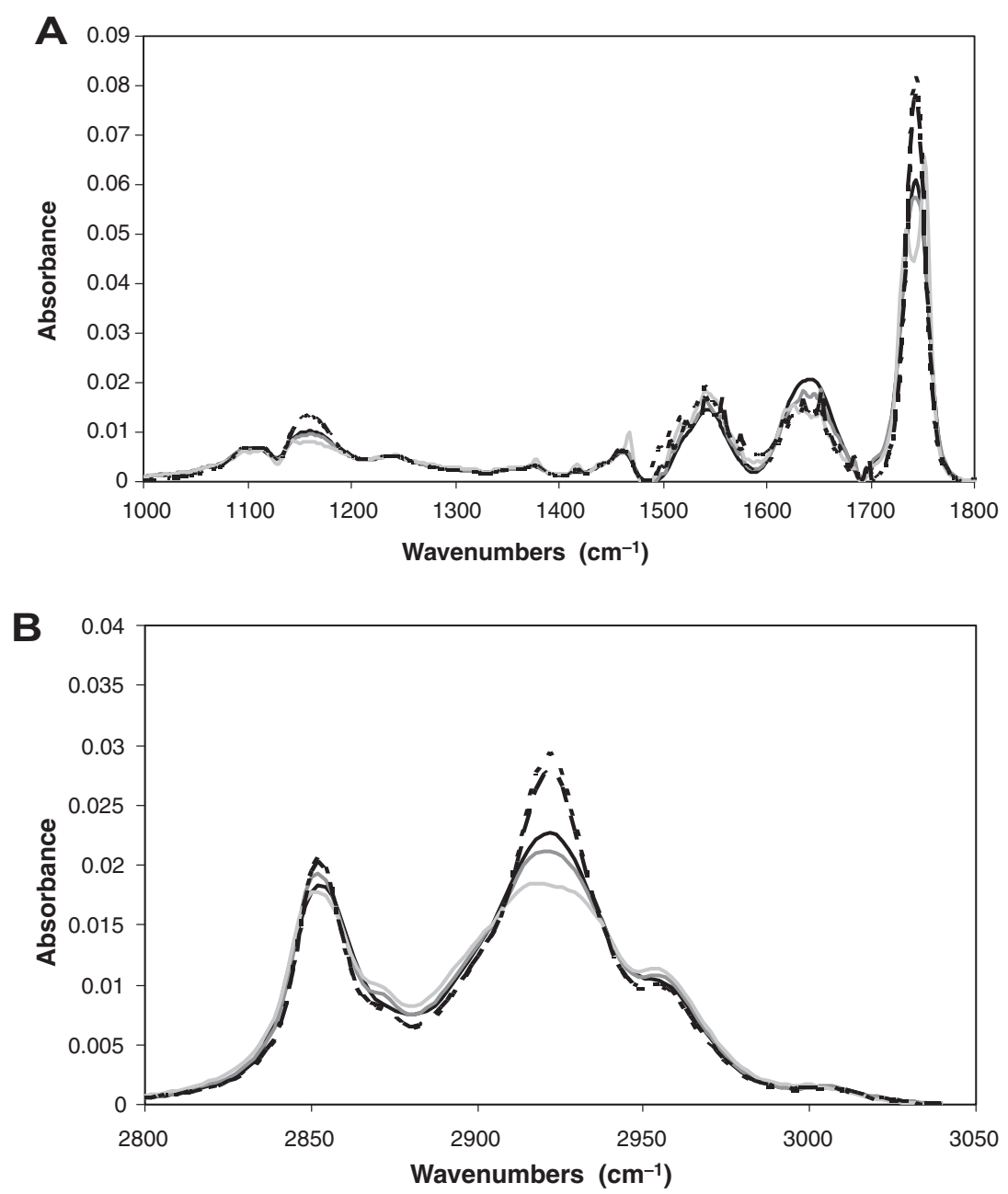

Figure 1. Evolution of Emmental cheese normalised infrared spectra (A: $1000-1800 \mathrm{~cm}^{-1}$, B: $\left.2800-3050 \mathrm{~cm}^{-1}\right)$ during ripening $(-\mathrm{d} 20,-\mathrm{d} 34,-\mathrm{d} 58,--\mathrm{d} 65,-\cdots \mathrm{MO})$.

it gradually decreased during ripening in the hot cellar, until achieving the lowest concentration at $\mathrm{d} 51\left(A_{51}=0.0063\right)$. This evolution is compatible with lactate progression in Emmental cheeses [4, 29]. These authors showed that in this type of cheese, after reaching a maximum at about $\mathrm{d} 30$, the lactate concentration gradually diminished throughout the rest of the ripening period.
This reduction was more marked during the ripening into the hot cellar $\left(20-24{ }^{\circ} \mathrm{C}\right)$ $[4,29]$.

Two well-defined peaks were observed in the frequency range $1700-1490 \mathrm{~cm}^{-1}$ to the Amide I at $\sim 1647 \mathrm{~cm}^{-1}(v \mathrm{C}=\mathrm{O}, v \mathrm{C}-\mathrm{N})$ and Amide II at $\sim 1541 \mathrm{~cm}^{-1}(\delta \mathrm{N}-\mathrm{H}$ and $v$ C-N) (Fig. 1). These two peaks are associated with hydrolysed proteins [26]. 
Table I. ANOVA and Fisher LSD test $(P \leq 0.05)$ of infrared spectra of Emmental cheeses measured at different ripening times.

\begin{tabular}{lcccccccc}
\hline $\begin{array}{l}\text { Absorption band } \\
\left(\mathrm{cm}^{-1}\right)\end{array}$ & $P$ value & \multicolumn{7}{c}{ Ripening day } \\
\cline { 3 - 9 } & & $\mathrm{d} 20$ & $\mathrm{~d} 27$ & $\mathrm{~d} 34$ & $\mathrm{~d} 51$ & $\mathrm{~d} 58$ & $\mathrm{~d} 65$ & $\mathrm{MO}$ \\
\hline $1115($ Lactate) & $0.0000^{*}$ & $0.006366^{\mathrm{a}}$ & $0.006504^{\mathrm{c}}$ & $0.00650^{\mathrm{bc}}$ & $0.006381^{\mathrm{a}}$ & $0.006340^{\mathrm{a}}$ & $0.00641^{\mathrm{ab}}$ & $0.006612^{\mathrm{d}}$ \\
1161 (Lactose $+\mathrm{ms})$ & $0.0000^{*}$ & $0.00999^{\mathrm{bc}}$ & $0.00976^{\mathrm{bc}}$ & $0.010179^{\mathrm{b}}$ & $0.00929^{\mathrm{ac}}$ & $0.008855^{\mathrm{a}}$ & $0.009027^{\mathrm{a}}$ & $0.012926^{\mathrm{d}}$ \\
$1541($ (Amide II) & $0.0000^{*}$ & $0.01624^{\mathrm{ab}}$ & $0.016849^{\mathrm{b}}$ & $0.01591^{\mathrm{ab}}$ & $0.013084^{\mathrm{c}}$ & $0.01409^{\mathrm{ac}}$ & $0.01629^{\mathrm{ab}}$ & $0.019678^{\mathrm{d}}$ \\
$1647($ Amide I) & $0.0000^{*}$ & $0.019608^{\mathrm{c}}$ & $0.017351^{\mathrm{b}}$ & $0.017849^{\mathrm{b}}$ & $0.014852^{\mathrm{a}}$ & $0.015160^{\mathrm{a}}$ & $0.016646^{\mathrm{b}}$ & $0.013881^{\mathrm{a}}$ \\
$1743(\mathrm{C}=\mathrm{O})$ & $0.0000^{*}$ & $0.06016^{\mathrm{bc}}$ & $0.05859^{\mathrm{bc}}$ & $0.060978^{\mathrm{c}}$ & $0.05646^{\mathrm{ab}}$ & $0.052419^{\mathrm{a}}$ & $0.053959^{\mathrm{a}}$ & $0.079408^{\mathrm{d}}$ \\
$2852\left(\mathrm{CH}_{2}\right)$ & $0.0032^{*}$ & $0.018502^{\mathrm{a}}$ & $0.019306^{\mathrm{a}}$ & $0.019271^{\mathrm{a}}$ & $0.018541^{\mathrm{a}}$ & $0.018472^{\mathrm{a}}$ & $0.018988^{\mathrm{a}}$ & $0.020224^{\mathrm{b}}$ \\
$2872\left(\mathrm{CH}_{3}\right)$ & $0.0000^{*}$ & $0.008648^{\mathrm{b}}$ & $0.00911^{\mathrm{cd}}$ & $0.00889^{\mathrm{bc}}$ & $0.00942^{\mathrm{ad}}$ & $0.009656^{\mathrm{a}}$ & $0.009498^{\mathrm{a}}$ & $0.008046^{\mathrm{e}}$ \\
$2922\left(\mathrm{CH}_{2}\right)$ & $0.0000^{*}$ & $0.022403^{\mathrm{b}}$ & $0.02157^{\mathrm{bc}}$ & $0.022698^{\mathrm{b}}$ & $0.02022^{\mathrm{ac}}$ & $0.018935^{\mathrm{a}}$ & $0.019801^{\mathrm{a}}$ & $0.028161^{\mathrm{d}}$ \\
$2956\left(\mathrm{CH}_{3}\right)$ & $0.0000^{*}$ & $0.010341^{\mathrm{a}}$ & $0.01063^{\mathrm{bc}}$ & $0.01049^{\mathrm{ab}}$ & $0.01080^{\mathrm{cd}}$ & $0.011133^{\mathrm{e}}$ & $0.01090^{\mathrm{de}}$ & $0.009842^{\mathrm{f}}$ \\
\hline
\end{tabular}

ms: monosaccharides.

* Significant at $P \leq 0.05$.

${ }^{\mathrm{a}-\mathrm{f}}$ Mean values without a common letter are significantly different $(P \leq 0.05)$.

The ANOVA results showed that the absorbance change throughout ripening was significant for both bands (Tab. I). These bands showed different patterns. Amide I band showed a reduction from $\mathrm{d} 20$ $\left(A_{20}=0.0019\right)$ to $\mathrm{d} 27\left(A_{27}=0.0017\right)$ (temperate cellar), then remained the same until the end of ripening (hot cellar to $\mathrm{MO}$ ). On the other hand, Amide II band showed a two-stage evolution; initially the signal stayed stable until $\mathrm{d} 34\left(A_{34}=0.016\right)$ and then increased significantly until $\mathrm{MO}$ $\left(A_{85}=0.0197\right)$ (Tab. I).

This spectral evolution was consistent with the proteolysis phenomenon reported for Swiss-type and Emmental cheeses [27, 30]. A slow proteolysis occurred at the beginning of ripening due to plasmin inactivation during high-temperature cooking of those cheeses [7]. The highest proteolysis occurred in the hot cellar due to the propionic bacterial growth [7, 27]. Changes in these bands in the $1700-1490 \mathrm{~cm}^{-1}$ range have been associated with modifications in the secondary structure of casein, protein aggregation and protein-water interactions $[15,20,31]$.

The region between 3050 and $2800 \mathrm{~cm}^{-1}$ (Fig. 1B) showed bands that were characteristic of hydrocarbon chains [25]. Two major bands corresponding to methylene groups at $\sim 2922 \mathrm{~cm}^{-1}\left(v_{\mathrm{as}} \mathrm{CH}_{2}\right)$ and $\sim 2852 \mathrm{~cm}^{-1}$ $\left(v_{\mathrm{s}} \mathrm{CH}_{2}\right)$, as well as two minor bands corresponding to methyl groups at $\sim 2956 \mathrm{~cm}^{-1}$ $\left(v_{\text {as }} \mathrm{CH}_{3}\right)$ and $\sim 2872 \mathrm{~cm}^{-1}\left(v_{\mathrm{s}} \mathrm{CH}_{3}\right)$ were observed. The observed absorbance changes were significant for both functional groups (Tab. I). In both cases the signals remained steady until d58 $\left(A_{58}=0.0198\right.$ and 0.019 for methylene groups, respectively; $A_{65}=0.0109$ and 0.0095 for methyl groups, respectively), whereas from d65 until the end of ripening, the methyl signal significantly decreased $\left(A_{85}=0.0098\right.$ and 0.0080 , respectively) and that of methylene increased $\left(A_{85}=0.0281\right.$ and 0.0202 , respectively). The observed changes in methyl and methylene bands have been described previously by other authors $[5,15,16]$ and were attributed [5] to a change in the physical state of cheese triglycerides.

The peak at $\sim 1743 \mathrm{~cm}^{-1}(v-\mathrm{C}=\mathrm{O})$, associated with esters and organic acids, remained steady until d58 $\left(A_{58}=0.054\right)$, then increased significantly $\left(A_{85}=0.079\right)$ to the end of ripening (Tab. I). A reduction in the intensity of this band has been associated with lactate consumption [16] while the increment with the higher concentration of carbonyl groups generated during lipolysis 
and proteolysis [3]. In Swiss-type cheeses such as Emmental, the most important occurrence of lactate consumption and lipolysis has been reported during the hot cellar ripening period $[2,4,22]$ when propionic bacteria grow. The observed behaviour could be attributed to the fact that lipolysis, proteolysis and lactate consumption were equally significant until d65, but after d65 lactate consumption was less important compared to the other phenomena.

\subsection{PCA}

Application of PCA to the normalised spectral set made it possible to obtain important information that described the spectral changes throughout ripening and the association with corresponding biochemical reactions.

The PCA factorial map of Emmental cheese spectra is shown in Figure 2A. It is defined by PC1 and PC2 which account for $44.9 \%$ and $26.0 \%$ of the total variance, respectively. Four groups of samples can be described corresponding to the different stages of the ripening process. The first group (G1) included samples ripened in the temperate chamber $(\mathrm{d} 20, \mathrm{~d} 27$ and $\mathrm{d} 34)$ and it was separated from the other groups mainly along axis 2 . Taking into account axis 1, it was possible to describe three other groups and the evolution of the ripening process from d51 until MO by separating the d51/d58 (G2), d65 (G3) and MO (G4) samples (Fig. 2A).

The eigenvectors corresponding to $\mathrm{PC} 1$ and PC2 are shown in Figure 2B. They provide important information about the vibrations describing cheese spectral evolution throughout ripening and the biochemical reactions involved. Eigenvector 1 shows several peaks in the region between 1490 and $1800 \mathrm{~cm}^{-1}$, a relevant peak at $\sim 1743 \mathrm{~cm}^{-1}(-\mathrm{C}=\mathrm{O})$ and Amide II peak at $1552 \mathrm{~cm}^{-1}$. At $2921 \mathrm{~cm}^{-1}$ appeared a peak corresponding to methylene $\left(\mathrm{CH}_{2}\right)$, whereas at $1169 \mathrm{~cm}^{-1}$ the one corresponding to ester links of fats $(v \mathrm{C}-\mathrm{O})$ appeared. Eigenvector 2 also showed the 1743 and $1169 \mathrm{~cm}^{-1}$ peaks, but they had a lower intensity and were in a different direction to their counterparts in eigenvector 1 . In the Amide region (1700-1490 $\mathrm{cm}^{-1}$ ), only Amide I $\left(1631 \mathrm{~cm}^{-1}\right)$ peak was observed. It was considered the most important signal of this vector. These observations suggest that both eigenvectors described the phenomena correlated with lactate consumption as well as proteolysis and lipolysis. The higher signal intensity of eigenvector 1 suggests that this vector was associated with the acceleration of the evolution rates of those phenomena in the hot cellar. Similar findings were described by many authors [2, $8,27,30]$.

The differences observed for the Amide peaks between PC1 and PC2 could be attributed to the proteolytic mechanisms involved [21, 28]. In the first days of ripening, the proteolysis is effectuated by plasmin that is stable at the cooking temperature producing intermediate-sized peptides from casein. Then in the hot cellar, the secondary flora are responsible for the proteolytic and peptidolytic phenomena. In this work, Propionibacterium used as secondary flora is not a strong proteolytic organism but is highly peptidolytic. Martín Del Campo et al. [19] observed differences in the Amide peaks in the spectra of soft mould-ripened cheeses. Those differences made it possible to describe the ripening of Camembert-type cheeses in two zones.

The spectral evolution in the Amide zone $\left(1700-1500 \mathrm{~cm}^{-1}\right)$ has been previously studied for semi-hard cheeses ripened at $13{ }^{\circ} \mathrm{C}$ [20] and for soft cheeses [15]. These authors observed similar bands in the eigenvectors and therefore also obtained good discrimination according to cheese age or ripening. Vannini et al. [31] found remarkable differences in Amide bands in terms of cheese age and the strain used. 

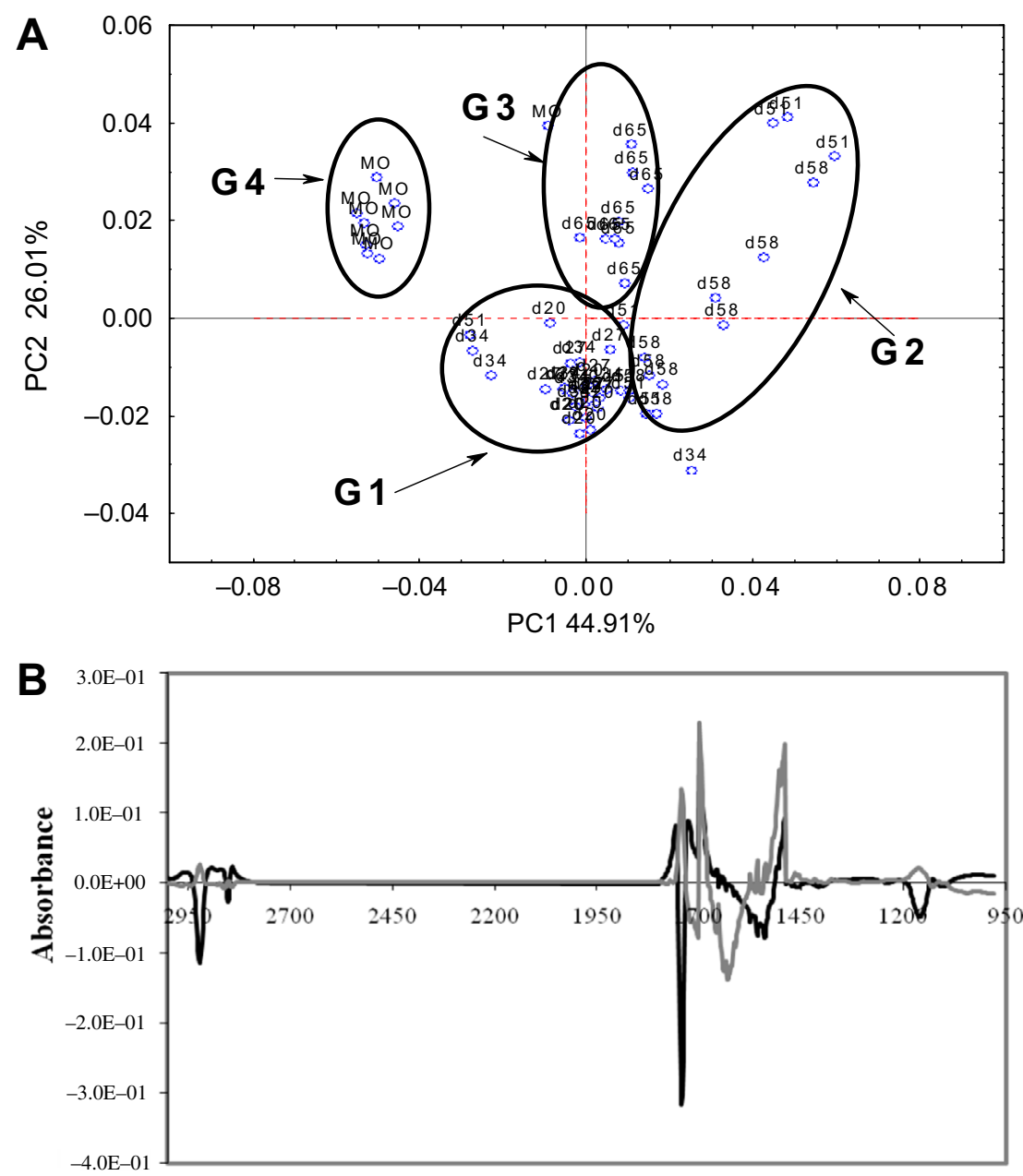

Figure 2. Emmental cheese spectra PCA plots of the first two components. PC1 and PC2: (A) factorial map and (B) eigenvectors ( $-\mathrm{PC} 1$ and $-\mathrm{PC} 2)$.

The band at $\sim 1743 \mathrm{~cm}^{-1}$, associated with lactate and free fatty acids, was previously observed for experimental cheeses $[16,19]$. In the present work, this band was present in both eigenvectors but it was comparatively more relevant in $\mathrm{PC} 1$ than in PC2. PC1 was related to spectral changes from $\mathrm{d} 58$ until $\mathrm{MO}$ at the end of ripening, a period when lipolytic activity was more important $[2,22]$.

\subsection{Discriminant analysis}

Forward stepwise discriminant analysis led to the selection of 24 wavenumbers ( $P$ inclusion 0.05 and $P$ exclusion 0.05 ), of which 18 corresponded to specific wavenumbers in the spectral region described in PCA. Four wavenumbers were selected for the $1743 \mathrm{~cm}^{-1}$ peak; three wavenumbers were selected for each of the $2852 \mathrm{~cm}^{-1}$ 
Table II. GDA of Emmental cheese infrared spectra (3030-2750 and $1800-950 \mathrm{~cm}^{-1}$ ). Classification according to the ripening age for the calibration, cross-validation and prediction models.

\begin{tabular}{lcccccccc}
\hline Model & \multicolumn{7}{c}{ Predicted age } & \% Correct classification \\
\cline { 2 - 7 } & $\mathrm{d} 20$ & $\mathrm{~d} 27$ & $\mathrm{~d} 34$ & $\mathrm{~d} 51$ & $\mathrm{~d} 58$ & $\mathrm{~d} 65$ & $\mathrm{MO}$ & \\
\hline Calibration & 100 & 100 & 100 & 100 & 100 & 100 & 100 & 100 \\
Cross-validation & 50 & 100 & 100 & 50 & 100 & 100 & 100 & 87 \\
Prediction & 0 & 100 & 50 & 50 & 50 & 50 & 100 & 57 \\
\hline
\end{tabular}

$\left(\mathrm{CH}_{2}\right)$ and $2956 \mathrm{~cm}^{-1}\left(\mathrm{CH}_{3}\right)$ peaks; only two wavenumbers were selected for each of the $2921 \mathrm{~cm}^{-1}\left(\mathrm{CH}_{2}\right)$ and the Amide I $\left(1631 \mathrm{~cm}^{-1}\right)$ peaks; and only one was selected for each of the $1115 \mathrm{~cm}^{-1}$, $1169 \mathrm{~cm}^{-1}$, Amide II $\left(1552 \mathrm{~cm}^{-1}\right)$ and $2872 \mathrm{~cm}^{-1}$ peaks (data not shown).

Classification of the cheese spectra according to the probability of belonging to a particular group is shown in Table II. While the levels of correct classification were high for the calibration and crossvalidation groups, the prediction group showed just $57 \%$ of correct classification. The poor success of the prediction can be explained by the lack of robustness of the model. But, it is also necessary to take into account the small number of samples of each class in the prediction set. With 14 samples in total, there are only 2 samples representing each class.

Figure 3 shows the predicted versus the expected values for the samples collected seven times during the ripening period. In fact, the misclassified samples appeared between $\mathrm{d} 20, \mathrm{~d} 27$ and $\mathrm{d} 34$ groups, then between $\mathrm{d} 51$ and $\mathrm{d} 58$ groups, and finally between $\mathrm{d} 65$ and MO (d85) groups with just one sample of MO group included in $\mathrm{d} 65$ group.

According to these observations, four groups could be distinguished as shown by the PCA, the first comprising samples from $\mathrm{d} 20$ until $\mathrm{d} 34$, corresponding to the youngest cheeses from the beginning of ripening until the entrance to the hot cellar.
The second group contained samples aged from d51 until d58 (middle of ripening), the third group included the d65 samples and the fourth group was formed by the oldest cheeses (d85). A discriminant analysis made on the basis of these four groups led to a correct classification rate of $100 \%$ for the three datasets: namely, calibration, cross-validation and prediction.

These results are consistent with the biochemical evolution of Emmental cheeses. At the initial stage of the ripening (before the transfer into the hot cellar), proteolysis and lipolysis were low [2, 21, 27, 28, 30]. Then, the higher ripening temperature in the hot cellar increased the total protein, non-casein nitrogen and non-protein nitrogen fraction contents of cheese juices $[27,30]$ as well as free fatty acids [2]. Additionally, the consumption of citric acid and $\mathrm{L}(+)$-lactic acid, as well as the production of propionic and acetic acids, has been observed during hot cellar ripening $[27,29]$. A moderate increase of the protein fraction content after the hot cellar ripening has also been reported [27, 30].

There are only few reports dealing with the discrimination using infrared spectroscopy of cheeses throughout ripening. Swiss-type cheeses have been classified according to the cheese type [24] or the production region [10, 11]. Karoui et al. [11] obtained different percentages of correct classification according to the production region for Emmental cheeses by using the infrared range used in this research work. 


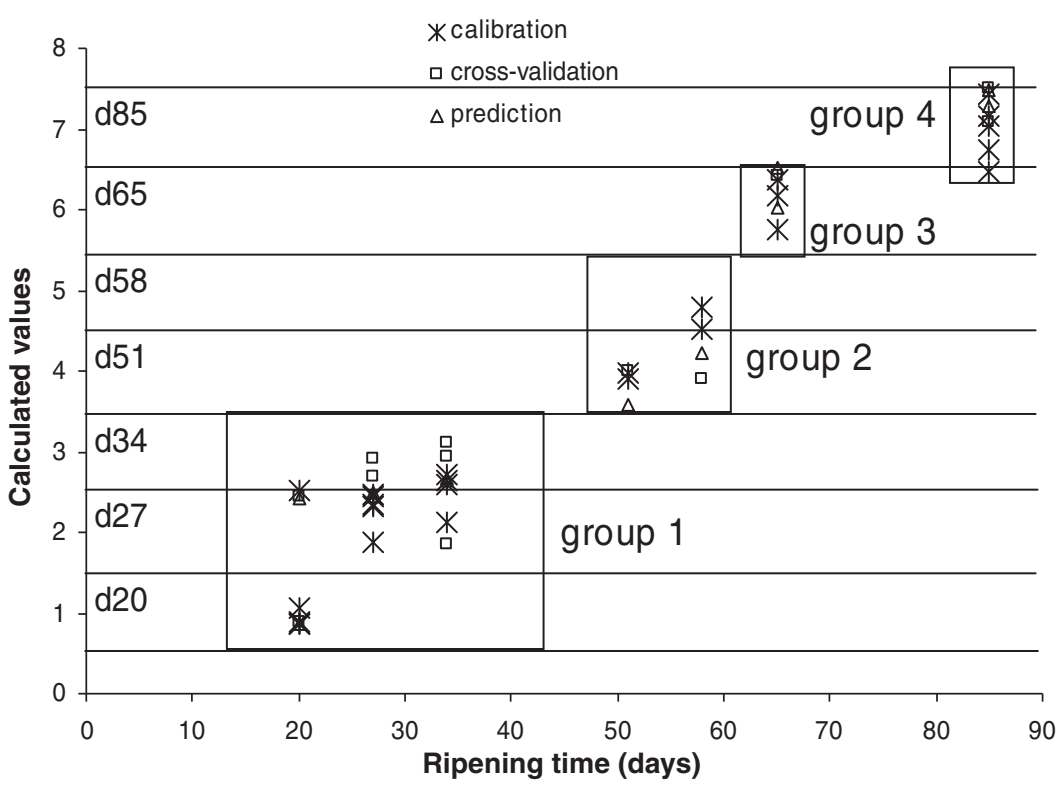

Figure 3. Calculated values versus expected values of the ripening time: $1=d 20,2=d 27,3=d 34$, $4=\mathrm{d} 51,5=\mathrm{d} 58,6=\mathrm{d} 65$ and $7=\mathrm{MO}$ (end of ripening).

The most significant changes throughout the ripening of semi-hard cheeses occurred in the methyl and methylene group spectral bands between 3000 and $2800 \mathrm{~cm}^{-1}$ regions [5] as observed in this study. These authors obtained a partial discrimination between cheeses with 1, 21, 51 and 81 days ripening by using PCA and canonical correlation analysis. They suggest that the viscosity of liquid triglycerides increased over time, resulting in the organisation of lipids. The effects of the ripening temperature on lipolysis were described by Chamba and Perreard, Ji et al., and Lopez et al. $[2,8,18]$. The total of free fatty acids did not change significantly during the storage of Emmental cheese at low temperature $\left(15^{\circ} \mathrm{C}\right)$. A significant increase was measured during the ripening at $21^{\circ} \mathrm{C}$ followed by a decrease during storage at $4{ }^{\circ} \mathrm{C}$. These evolutions of the concentration of free fatty acids are similar to those observed for the infrared spectra of cheeses in this study. The most significant changes of spectra took place during storage at 22$23{ }^{\circ} \mathrm{C}$ and at the end of the ripening after storage at $6{ }^{\circ} \mathrm{C}$. The important regions of the spectra for predicting age depend on the sort of cheese being analysed. The results of spectral analysis of Cheddar cheese [6] were in agreement with those presented by Dufour et al. [5] for Swiss-type cheeses, and these confirmed that the regions corresponding with lipids played a major role. Spectral zones assigned to carbohydrates (1150$950 \mathrm{~cm}^{-1}$ ), to lactate (around $1750 \mathrm{~cm}^{-1}$ ) and to protein $\left(1700-1490 \mathrm{~cm}^{-1}\right)$ provided excellent age predictions in mould-ripened soft cheeses [2, 8, 18].

\section{CONCLUSIONS}

ANOVA and PCA of Emmental cheese spectra made it possible to identify the spectral bands that exhibited significant changes throughout ripening. PCA made it possible 
to distinguish four groups and to describe a ripening evolution in three steps. The observed changes are associated with the evolution of the most important metabolites described for these sorts of cheeses.

On the other hand, the GDA of the sample spectra according to the seven ripening stages made it possible to obtain good calibration and cross-validation results, although the prediction results were weak with just $57 \%$ correct classification. The prediction of cheese age was good if four levels of ripening are defined on the basis of PCA results.

FTIR spectroscopy seems to be an interesting method to estimate the ripening stages of Emmental cheeses. However, a larger study will be necessary to confirm these results and to improve the robustness of the model on a larger set of manufactured samples. The implementation of spectroscopical measurements better adapted to cheeses and the creation of a more important spectral database allowing the elaboration of a robust model of prediction could supply an interesting tool for cheese makers to predict the maturity and to better understand the biochemical kinetics of ripening.

Acknowledgements: The authors would like to thank Actilait (former Institut Technique Français du Fromage, ITFF) for providing the cheese samples and Dr. S.R. Othón Saldívar, Professor of the Departamento de Biotecnología e Ingeniería de Alimentos, ITESM Campus Monterrey for the English language revision of the manuscript. S.T. Martín Del Campo would like to acknowledge the Consejo Nacional de Ciencia y Tecnología (CONACyT) for scholarship support during Ph.D. studies and the Programa de Cooperación de Posgrados (PCP) México-France for their financial support for the thesis project.

\section{REFERENCES}

[1] Cadet F., Safar M., Dufour E., Glucides, in: Bertrand D., Dufour E. (Eds.), La spectros- copie infrarouge et ses applications analytiques, Tec \& Doc, Paris, France, 2000.

[2] Chamba J.F., Perreard E., Contribution of propionic acid bacteria to lipolysis of Emmental cheese, Lait 82 (2002) 33-44.

[3] Chen M., Irudayaraj J., McMahon D.J., Examination of full fat and reduced fat Cheddar cheese during ripening by Fourier transform infrared spectroscopy, J. Dairy Sci. 81 (1998) 2791-2797.

[4] Choisy C., Desmazeaud M., Gripon J.C., Lamberet G., Lenoir J., La biochimie de l'affinage, in: Eck A., Gillis J.C. (Eds.), Le fromage, Lavoisier Tec \& Doc, Paris, France, 1997.

[5] Dufour E., Mazerolles G., Devaux M.F., Duboz G., Duployer M.H., Riou N.M., Phase transition of triglycerides during semi-hard cheese ripening, Int. Dairy J. 10 (2000) 81-93.

[6] Fagan C.C., O’Donnell C.P., O'Callaghan D.J., Downey G., Sheehan E.M., Delahunty C.M., Everard C., Guinee T.P., Howard V., Application of mid-infrared spectroscopy to the prediction of maturity and sensory texture attributes of Cheddar cheese, J. Food Sci. 72 (2007) E130-E137.

[7] Gagnaire V., Mollé D., Herrouin M., Léonil J., Peptides identified during Emmental cheese ripening: origin and proteolytic systems involved, J. Agric. Food Chem. 49 (2001) 4402-4413.

[8] Ji T., Alvarez V.B., Harper W.J., Influence of starter culture ratios and warm room treatment on free fatty acid and amino acid in Swiss cheese, J Dairy Sci. 87 (2004) 1986-1992.

[9] Karoui R., Bosset J.O., Mazerolles G., Kulmyrzaev A., Dufour E., Monitoring the geographic origin of both experimental French Jura hard cheeses and Swiss Gruyère and l'Etivaz PDO cheeses using mid-infrared and fluorescence spectroscopies: a preliminary investigation, Int. Dairy J. 15 (2005) 275-286.

[10] Karoui R., Dufour E., Pillonel L., Schaller E., Picque D., Cattenoz T., Bosset J.O., The potential of combined infrared and fluorescence spectroscopies as a method of determination of the geographic origin of Emmental cheeses, Int. Dairy J. 15 (2005) 287-298.

[11] Karoui R., Mazerolles G., Dufour E., Spectroscopic techniques coupled with chemometric tools for structure and texture 
determinations in dairy products, Int. Dairy J. 13 (2003) 607-620.

[12] Karoui R., Mouazen A., Dufour E., Schoonheydt R., Baerdemaeker J., A comparison and joint use of Vis-NIR and MIR spectroscopic methods for the determination of some chemical parameters in soft cheeses at external and central zones: a preliminary study, Eur. Food Res. Technol. 223 (2006) 363-371.

[13] Karoui R., Pillonel L., Schaller E., Bosset J.O., Baerdemaeker J.D., Prediction of sensory attributes of European Emmental cheese using near-infrared spectroscopy: a feasibility study, Food Chem. 101 (2006) 1121-1129.

[14] Koca N., Rodriguez-Saona L.E., Harper W.J., Alvarez V.B., Application of Fourier transform infrared spectroscopy for monitoring short-chain free fatty acids in Swiss cheese, J. Dairy Sci. 90 (2007) 3596-3603.

[15] Kulmyrzaev A., Dufour E., Noel Y., Hanafi M., Karoui R., Qannari E.M., Mazerolles G., Investigation at the molecular level of soft cheese quality and ripening by infrared and fluorescence spectroscopies and chemometrics - relationships with rheology properties, Int. Dairy J. 15 (2005) 669-678.

[16] Lanciotti R., Vannini L., Lopez C.C., Gobbetti M., Guerzoni M.E., Evaluation of the ability of Yarrowia lipolytica to impart strain-dependent characteristics to cheese when used as a ripening adjunct, Int. J. Dairy Technol. 58 (2005) 89-99.

[17] Lanher B., Spectrométrie infra-rouge à transformée de Fourier et analyse multidimensionnelle de données spectrales. Application à la quantification et au contrôle de procédés dans le domaine des produits laitiers, École Nationale Supérieure de Biologie Appliquée à l'Alimentation, Université de Bourgogne, Bourgogne, 1991.

[18] Lopez C., Maillard M.B., Briard-Bion V., Camier B., Hannon J.A., Lipolysis during ripening of Emmental cheese considering organization of fat and preferential localization of bacteria, J. Agric. Food Chem. 54 (2006) 5855-5867.

[19] Martín Del Campo S.T., Cosío-Ramírez R., Picque D., Corrieu G., Middle infrared spectroscopy characterization of ripening stages of Camembert-type cheeses, Int. Dairy J. 17 (2007) 835-845.

[20] Mazerolles G., Devaux M.F., Duboz G., Duployer M.H., Riou N.M., Dufour E., Infrared and fluorescence spectroscopy for monitoring protein structure and interaction changes during cheese ripening, Lait 81 (2001) 509-527.

[21] McSweeney P.L.H., Biochemistry of cheese ripening, Int. J. Dairy Technol. 57 (2004) $127-144$

[22] McSweeney P.L.H., Sousa M.J., Biochemical pathways for the production of flavour compounds in cheeses during ripening: a review, Lait 80 (2000) 293-324.

[23] Petibois C., Melin A.M., Perromat A., Cazorla G., Déléris G., Glucose and lactate concentration determination on single microsamples by Fourier-transform infrared spectroscopy, J. Lab. Clin. Med. 135 (2000) 210-215.

[24] Picque D., Cattenoz T., Corrieu G., Discrimination of Emmental cheeses by infrared spectroscopy, Milchwiss.-Milk Sci. Int. 57 (2002) 202-204

[25] Riaublanc A., Bertrand D., Dufour E., Lipides, in: Bertrand D., Dufour E. (Eds.), La spectroscopie infrarouge et ses applications analytiques, Tec \& Doc, Paris, France, 2000.

[26] Robert P., Dufour E., Règles générales d'attribution des bandes spectrales, in: Bertrand D., Dufour E. (Eds.), La spectroscopie infrarouge et ses applications analytiques, Tec \& Doc, Paris, France, 2000.

[27] Salvat-Brunaud D., Maubois J.L., Le Graet Y., Piot M., Maillard M.B., Corre C., Thierry A., Extraction et analyse de la phase aqueuse de 1'Emmental à 4 stades d'affinage, Lait 75 (1995) 239-249.

[28] Sousa M.J., Ardö Y., McSweeney P.L.H., Advances in the study of proteolysis during cheese ripening, Int. Dairy J. 11 (2001) 327-345.

[29] Steffen C., Flueckiger E., Bosset J.O., Ruegg M., Swiss-type varieties, in: Fox P.F. (Ed.), Cheese: Chemistry, Physics and Microbiology, Vol. 2. Major Cheese Groups, Elsevier Applied Science, London, UK, 1987.

[30] Thierry A., Salvat-Brunaud D., Madec M.N., Michel F., Maubois J.L., Affinage de l'Emmental : Dynamique des populations bactériennes et évolution de la composition de la phase aqueuse, Lait 78 (1998) 521-542.

[31] Vannini L., Baldi D., Lanciotti R., Use of Fourier transform infrared spectroscopy to evaluate the proteolytic activity of Yarrowia lipolytica and its contribution to cheese ripening, Int. J. Food Microbiol. 69 (2001) $113-123$. 